\title{
Komarek Levente
}

\section{A hazai baromfitenyésztés területi specializációjának jellemző vonásai napjainkban}

\author{
Levente Komarek \\ The Typical Features of the Regional Specialization in Poultry-Farming in \\ Hungary Today
}

\begin{abstract}
The territorial location issues of livestock in the European Union and also in our country have got into the focus over the past few years. There are different animal structures in the regions of our country and different animal species have become dominant. The location and the development of certain animal types are affected by a number of socio-economic factors (the history of breeding, ownership, labour and capital assets, etc.). In the case of the spatially differentiated species-structure we have to reckon with a variable profitability, human resources, technical standards, different risk factors and market opportunities in the different regions. The topicality of the research theme is enhanced by the fact that nowadays the spatial structure of animal production has become a key issue. That is why more and more research is needed in Hungary, primarily research studying and analysing the structural changes and principals of animal production (poultry production) in order to ensure that each region would have a rational and efficient breed-structure. In addition, it is expected in modern market economies that the various regions should specialize in animal species, for which they have the most favourable breeding conditions. In order to follow the poultry stock changes (spatial and structural) in the last decade, it was important to consider the spatial specialization of different species over time.

Keywords: poultry stock, hen, turkey, goose, duck, spatial specialisation
\end{abstract}

Összefoglaló

$A z$ elmúlt évek során az Európai Unióban és hazánkban is egyre inkább elötérbe kerültek az állatfajták elhelyezkedésének területi kérdései. Hazánk egyes térségeiben eltérö állatfajtastruktúra alakult ki és egy-egy régióban különbözö állatfajták váltak meghatározóvá. Az egyes állatfajták területi elhelyezkedését és fejlödését számos társadalmi-gazdasági tényezö (a tenyésztés történelmi hagyományai, a tulajdonviszonyok, a munkaerö- és eszközellátottság, stb.) befolyásolja. A területileg differenciált állatfajta-struktúra esetében az egyes térségekben változó jövedelmezöséggel, humán-eröforrás felhasználással, müszaki színvonallal, más-más kockázati tényezökkel és piaci lehetőségekkel kell számolni. A kutatási téma aktualitását fokozza, hogy napjainkban az állattenyésztés területi struktúrájának alakulása fontos kulcskérdéssé vált. Éppen 
ezért egyre inkább olyan hazai kutatásokra van szükség, amely elsősorban az állattenyésztés (baromfitenyésztés) szerkezeti átalakulását és annak törvényszerüségeit vizsgálja és elemzi, annak érdekében, hogy az egyes térségekben racionális és hatékonyan müködö állatfajtastruktúra alakuljon ki. E mellett a modern piacgazdaságokban elvárható, hogy az egyes térségek azokra az állatfajtákra specializálódjanak, amelyek esetében kedvezöbbek a tenyésztési feltételek. Annak érdekében, hogy az elmúlt egy évtized baromfiállomány változásait (területi, szerkezeti) figyelemmel tudjuk kísérni, fontosnak tartottam megvizsgálni az egyes baromfifajták térségek szerint specializációjának időbeni alakulását.

Kulcsszavak: baromfiállomány, tyúk, pulyka, lúd, kacsa, területi specializáció

\section{BEVEZETÉS}

$\mathrm{Az}$ elmúlt évtizedekben a világ baromfitenyésztése jelentős fejlődésen ment keresztül. A fejlődés eredményeképpen a baromfitenyésztés területén pozitív irányú változások következtek be. A pozitív irányú változások megmutatkoztak a termelés volumenének növekedésében, amelynek fö oka, hogy dinamikusan emelkedett a baromfitermékek iránti fizetőképes kereslet. $\mathrm{E}$ mellett az olcsó állati fehérje iránti növekvő igény is tovább fokozta a termelés volumenének emelkedését. Ezzel párhuzamosan szükségessé vált az integrált termelés fejlesztése főleg azokban a térségekben és országokban, ahol a fogyasztók egyre nagyobb igényeket támasztottak a termékek minőségével kapcsolatban. Ilyen igények a fejlett országokban, különösen az Európai Unió országaiban jelentkeztek. A baromfitenyésztésben a vertikális integráció a leginkább alkalmazott közgazdasági modell. A viszonylag rövid termelési ciklus, a nagy mennyiség, a tervezhetőség, de főleg a gazdaságosság kérdése kényszeríti ki a koordinációt és a kooperációt a termékpálya szereplői között (szaporítás, keltetés, takarmányozás, tenyésztés, feldolgozás, értékesítés) (Szőllősi 2008, Popp et. al. 2003).

Hazánk mezőgazdaságában az állattenyésztésnek és ezen belül a baromfitenyésztésnek hosszú éveken keresztül kitüntetett szerepe volt, amely szoros kölcsönhatásban állt a növénytermesztés struktúrájával és színvonalával (Komarek 2007, 2008c).

A tervgazdálkodás évtizedeiben az erőteljes iparosítás következtében a mezőgazdaság súlya, szerepe az egész nemzetgazdaságon belül az 1938 előtti helyzethez viszonyítva lényegesen csökkent. Ez a csökkenés azonban dinamikus fejlődés- és növekedés mellett következett be. Főleg 1961-től a mezőgazdaság nagyüzemi átszervezését követően születtek látványos eredmények. A hazai baromfitenyésztés jelentős fejlődése az 1970-es években következett be a vertikális integrációknak köszönhetően. A különböző termelési rendszerek integrációi biztosították azt a szellemi, technikai, technológiai, gazdasági és piaci hátteret, amely a baromfitenyésztés dinamikus fejlődését eredményezte. Ennek következtében az 1980-as évekre hazánk önellátási foka baromfihúsból 180\% körül stabilizálódott. Ehhez hozzájárult a gabonatermesztés jelentős növekedése és a baromfihús iránti piaci kereslet dinamikus emelkedése. A 80-as évek közepén a mezőgazdaságunk számos mutatója vonatkozásában a világ élvonalába került annak ellenére, hogy a hozamok, az előállítási költségek, illetve a termelési struktúra, a piacokhoz való alkalmazkodás gyorsasága, az élelmiszergazdasági vertikum elemei közti 
Komarek Levente: A hazai baromfitenyésztés területi specializációjának jellemző vonásai ...

összhang megteremtése terén még sok tennivalónk volt. Az 1980-as évek közepéig az egyenlőtlen ütem ellenére is lendületes fejlődést tapasztalhattunk, majd azt követően különböző feszültségek, egyensúlytalanságok kerültek felszínre a mezőgazdaság (állattenyésztés, növénytermesztés) területén (Bodnár et. al. 2005, Komarek 2003, 2004, Troján 2010, Popp 2008a, 2008b).

A rendszerváltozás után olyan mélyreható változások következtek be az állattenyésztés valamennyi ágazatában, hogy teljesen új helyzet állt elő. Ezek a változások érzékenyen érintették a magyar baromfivertikumot. Csökkent a feldolgozó ágazat árualapja, megváltozott az üzemméret, az állomány területi struktúrája, volumene, fajtaösszetétele, jövedelmezősége, romlottak a belső- és külső értékesítési lehetőségek (Komarek 2008b, 20011, Popp 2014)

Jelentősen átalakult a feldolgozóipar is. Megváltozott a tulajdonosi szerkezet, a mikro szintű koncentráció, a kapacitás, az árualap- és termékstruktúra, a termelékenység, a piaci viszonyok és az exportlehetőség. Módosult az élelmiszergazdaságban betöltött szerepe. Az alacsony jövedelmezőségi szint indokolatlan termelés-visszaeséseket eredményezett, továbbá oda vezetett, hogy az állatállományunk és ezen belül a baromfiállományunk létszáma napjainkra soha nem tapasztalt mélységbe zuhant (Komarek 2008a, 2008b, Popp 2013, 2014).

A baromfivertikum múszaki fejlesztése a rendszerváltozás utáni években is folytatódott. A fejlett országok színvonalától mind a baromfitenyésztés, mind a feldolgozás területén vannak lemaradásaink. Elengedhetetlen a baromfitenyésztés hatékonyságának növelése, de fontos a feldolgozás műszaki színvonalának további emelése is (Komarek 2008c).

\section{ANYAG ÉS MÓDSZER}

A vizsgálathoz adatforrásként a Központi Statisztikai Hivatal (KSH) által rendelkezésre álló statisztikai adatokat használtam fel. Az adatokból olyan mutatót képeztem, amely lehetővé tette a baromfitenyésztés területi összehasonlítását. Ennek alapján a vizsgálat tárgyát a tyúk, a pulyka, a lúd és a kacsa állományának időbeni és területi adatai képezték a 2004 és 2013 közötti időszakban.

$\mathrm{Az}$ elmúlt években és napjainkban is a hazai mezőgazdaság átalakulása az állattenyésztés és ezen belül a baromfitenyésztés ágazati és területi struktúrájában is jelentős változásokat eredményezett. Ezek a változások szükségessé teszik olyan vizsgálatok elvégzését, amelyek válaszokat adnak arra vonatkozóan, hogy a baromfitenyésztés térbeli szerveződésénél megfigyelhető-e területi specializáció. Ezen feltevések megválaszolására a területi kutatásoknál használatos matematikaistatisztikai módszert alkalmaztam.

A specializáció mérésének elterjedt módszere az ún. területi specializációs mutató. Ezen mutató megmutatja az egyes területegységek országos részarányának alakulását az adott termék vagy termelési ág vonatkozásában. Ilyen az ún. közönséges specializációs mutató. Általános képlete:

$$
S_{k \ddot{z} z}=\frac{x_{r}}{x_{t}} \times \frac{t}{r}
$$

ahol:

$S_{\text {köz }}=$ a közönséges specializációs mutató

$\mathrm{x}_{\mathrm{r}}=\mathrm{a}$ területegység értéke

$x_{t}=a z$ országos érték

$\mathrm{t}=\mathrm{az}$ ország területe

$r=a$ vizsgált területegység területe 
A közönséges specializációs mutató megmutatja, hogy egy termék vagy egy ágazat termelésének vonatkozásában milyen mértékben részesedik az országos értékből. Minél magasabb a specializációs mutató értéke, annál nagyobb lesz a specializáció mértéke.

\section{EREDMÉNYEK}

A hazai baromfiállomány területi specializációjának időbeni alakulását vizsgálva a számított adatokból általánosságban megállapítható, hogy az egyes baromfifajták esetében a specializáció mértékében változás következett be. Vannak olyan térségek, ahol a specializáció mértéke az adott állatfajták esetében erősödött és vannak olyanok, amelyek veszítettek súlyokból, szerepükből a vizsgált időszak alatt.

\subsection{A hazai tyúktenyésztés területi specializációja}

A tyúkállomány az elmúlt években hektikusan alakult, de tendenciáját tekintve csökkenő. Az állomány változását hullámhegyek és hullámvölgyek egyaránt jellemezték. 2004-ben még 32814 ezer darab volt a tyúkállomány, ami 2013-ra 29474 ezer darabra csökkent, amely egyben a vizsgált időszak legkisebb állományát is jelenti. Az állomány csökkenésének oka elsősorban a tőkehiány (az adott szektor minden szintjén), a rendelkezésre áló infrastruktúra olykor elavult állapota, a nem megfelelő termelési paraméterek, a vágókapacitások alacsony kihasználtsága, illetve az egységes (EU) piacon belül az olcsó import megjelenése. E mellett az Európai Unió által előírt tartási körülmények szigorítása is megemlíthető, amelynek eredményeképpen több tenyésztő a tyúktenyésztés feladására és fokozatos leépítésére kényszerült. Ennek ellenére napjainkban a baromfiállományon belül a tyúkfélék aránya megközelíti a 78\%-ot.

A tyúkállomány esetében a bázisévben (2004) a legnagyobb specializáltságot KomáromEsztergom megye képviselte. Országosan a legmagasabb fokú specializációval jellemezhető megye volt a tyúktenyésztés területén. Ezen megye mellett még megemlíthető Hajdú-Bihar, Baranya, illetve Bács-Kiskun és Csongrád megye is, de ezen megyék specializációs mutatója azonban jóval elmarad Komárom-Esztergom megye mutatójától.

A tárgyévre (2013) Komárom-Esztergom megye erőteljes specializáltságából igaz, hogy veszített, de még mindig meghatározó megye maradt a tyúktenyésztés területén. Hajdú-Bihar megyében növekedett, Baranya megyében pedig csökkent a specializáció értéke és ezen keresztül a mértéke is a bázisévről a tárgyévre. Szintén említést érdemlő specializációnövekedés tapasztalható a fővárosban, Szabolcs-Szatmár-Bereg és Zala megyében, ami azt jelenti, hogy a tyúktenyésztés területi struktúrája folyamatos változás alatt van. Egyes térségek súlya és szerepe a tyúktenyésztés területén növekszik, míg másoké pedig csökken (pl. Bács-Kiskun, Csongrád megye).

1. táblázat: A hazai tyúktenyésztés területi specializációja

\begin{tabular}{|l|c|c|c|c|c|c|c|c|c|c|}
\hline Területegység & $\mathbf{2 0 0 4}$ & $\mathbf{2 0 0 5}$ & $\mathbf{2 0 0 6}$ & $\mathbf{2 0 0 7}$ & $\mathbf{2 0 0 8}$ & $\mathbf{2 0 0 9}$ & $\mathbf{2 0 1 0}$ & $\mathbf{2 0 1 1}$ & $\mathbf{2 0 1 2}$ & $\mathbf{2 0 1 3}$ \\
\hline Budapest & 0,67 & 0,63 & 1,13 & 1,23 & 1,30 & 0,86 & 1,18 & 1,41 & 0,84 & 2,16 \\
\hline Pest & 0,95 & 1,07 & 0,89 & 0,77 & 1,06 & 0,78 & 0,67 & 0,82 & 0,87 & 1,03 \\
\hline Közép-Magyarország & $\mathbf{0 , 9 0}$ & $\mathbf{0 , 9 7}$ & $\mathbf{0 , 9 5}$ & $\mathbf{0 , 8 7}$ & $\mathbf{1 , 1 1}$ & $\mathbf{0 , 7 9}$ & $\mathbf{0 , 7 7}$ & $\mathbf{0 , 9 4}$ & $\mathbf{0 , 8 7}$ & $\mathbf{1 , 2 6}$ \\
\hline Fejér & 0,83 & 0,80 & 0,74 & 0,61 & 0,53 & 0,83 & 0,77 & 0,67 & 0,67 & 0,69 \\
\hline Komárom-Esztergom & 5,00 & 5,58 & 5,38 & 4,54 & 4,01 & 5,06 & 6,25 & 6,55 & 3,32 & 3,47 \\
\hline Veszprém & 0,70 & 0,59 & 0,61 & 0,68 & 0,85 & 0,72 & 0,68 & 0,58 & 0,71 & 0,76 \\
\hline Közép-Dunántúl & $\mathbf{1 , 6 6}$ & $\mathbf{1 , 6 9}$ & $\mathbf{1 , 6 3}$ & $\mathbf{1 , 4 3}$ & $\mathbf{1 , 3 6}$ & $\mathbf{1 , 6 5}$ & $\mathbf{1 , 8 8}$ & $\mathbf{1 , 8 5}$ & $\mathbf{1 , 2 3}$ & $\mathbf{1 , 2 9}$ \\
\hline Győr-Moson-Sopron & $\mathbf{0 , 9 9}$ & $\mathbf{0 , 7 1}$ & 0,91 & 0,96 & 0,69 & $\mathbf{0 , 8 5}$ & $\mathbf{0 , 8 3}$ & 0,84 & 0,92 & 0,96 \\
\hline
\end{tabular}


Komarek Levente: A hazai baromfitenyésztés területi specializációjának jellemző vonásai ...

\begin{tabular}{|c|c|c|c|c|c|c|c|c|c|c|}
\hline Vas & 0,87 & 0,79 & 0,81 & 0,60 & 0,95 & 1,18 & 0,93 & 0,87 & 0,87 & 0,94 \\
\hline Zala & 0,93 & 1,10 & 1,07 & 0,91 & 1,37 & 1,18 & 0,76 & 0,87 & 1,25 & 1,21 \\
\hline Nyugat-Dunántúl & 0,93 & 0,86 & 0,93 & 0,84 & 0,99 & 1,05 & 0,84 & 0,86 & 1,01 & 1,04 \\
\hline Baranya & 1,37 & 1,45 & 1,26 & 1,37 & 1,35 & 1,17 & 1,32 & 1,18 & 1,10 & 1,03 \\
\hline Somogy & 0,37 & 0,42 & 0,47 & 0,46 & 0,34 & 0,30 & 0,33 & 0,23 & 0,25 & 0,29 \\
\hline Tolna & 0,52 & 0,66 & 0,57 & 0,56 & 0,56 & 0,45 & 0,47 & 0,46 & 0,42 & 0,45 \\
\hline Dél-Dunántúl & 0,73 & 0,82 & 0,75 & 0,78 & 0,72 & 0,62 & 0,69 & 0,60 & 0,57 & 0,57 \\
\hline Borsod-Abaúj-Zemplén & 0,85 & 0,77 & 0,89 & 1,04 & 1,02 & 0,99 & 0,82 & 0,71 & 0,70 & 0,78 \\
\hline Heves & 0,32 & 0,29 & 0,38 & 0,27 & 0,29 & 0,28 & 0,38 & 0,28 & 0,28 & 0,41 \\
\hline Nógrád & 0,36 & 0,41 & 0,36 & 0,39 & 0,31 & 0,36 & 0,30 & 0,31 & 0,25 & 0,35 \\
\hline Észak-Magyarország & 0,61 & 0,56 & 0,64 & 0,69 & 0,67 & 0,66 & 0,59 & 0,51 & 0,49 & 0,59 \\
\hline Hajdú-Bihar & 1,51 & 1,74 & 1,75 & 2,09 & 1,75 & 1,72 & 2,07 & 1,66 & 2,29 & 1,94 \\
\hline Jász-Nagykun-Szolnok & 0,71 & 0,69 & 0,56 & 0,61 & 0,65 & 0,45 & 0,40 & 0,39 & 0,42 & 0,44 \\
\hline Szabolcs-Szatmár-Bereg & 0,98 & 1,20 & 1,32 & 1,57 & 1,29 & 1,62 & 1,69 & 2,04 & 1,95 & 1,87 \\
\hline Észak-Alföld & 1,06 & 1,21 & 1,21 & 1,42 & 1,23 & 1,27 & 1,39 & 1,38 & 1,56 & 1,43 \\
\hline Bács-Kiskun & 1,26 & 1,08 & 1,16 & 1,03 & 1,24 & 1,13 & 0,91 & 0,96 & 1,33 & 0,99 \\
\hline Békés & 0,81 & 0,82 & 0,68 & 0,62 & 0,77 & 0,62 & 0,51 & 0,61 & 0,58 & 0,70 \\
\hline Csongrád & 1,26 & 0,74 & 0,71 & 0,80 & 0,64 & 0,86 & 0,92 & 1,02 & 1,00 & 0,88 \\
\hline Dél-Alföld & 1,13 & 0,92 & 0,91 & 0,86 & 0,96 & 0,92 & 0,79 & 0,87 & 1,03 & 0,88 \\
\hline
\end{tabular}

\subsection{A hazai pulykatenyésztés területi} specializációja

A tyúkállományhoz hasonlóan a pulykaállomány létszáma is csökkenő tendenciát mutat a vizsgált időszakban. Az állomány mennyisége 2004-ben 3592 ezer darab volt, amely 2013-ra 2530 ezer darabra csökkent. 2010-ről 2011-re évi 169 ezer darabbal, míg 2012-ről 2013-ra már évi 268 ezer darabbal csökkent hazánk pulykaállománya. Az állomány csökkenésének oka a viszonylag magas takarmány- és energiaárakkal magyarázható. E mellett a felvásárlási árak olykor nem fedezik a tenyésztők önköltségét sem. A kialakult piaci anomáliák és nehézségek kiszámíthatatlanná teszik a termelési költségeket, és jelentős veszteségeket okoznak.

A pulykaállomány esetében 2004-ben a legnagyobb specializáltságot Vas megye képviselte. E mellett még Győr-Moson-Sopron, Békés, Zala és Somogy megye említhető meg. 2013-ra Vas megyében csökkent, ezzel szemben Győr-Moson-Sopron, Zala és Hajdú-Bihar megyében növekedett a területi specializáltság. Békés megyét a bázisévről a tárgyévre a stagnálás jellemezte.

2. táblázat: A hazai pulykatenyésztés területi specializációja

\begin{tabular}{|l|c|c|c|c|c|c|c|c|c|c|}
\hline Területegység & $\mathbf{2 0 0 4}$ & $\mathbf{2 0 0 5}$ & $\mathbf{2 0 0 6}$ & $\mathbf{2 0 0 7}$ & $\mathbf{2 0 0 8}$ & $\mathbf{2 0 0 9}$ & $\mathbf{2 0 1 0}$ & $\mathbf{2 0 1 1}$ & $\mathbf{2 0 1 2}$ & $\mathbf{2 0 1 3}$ \\
\hline Budapest & 0,00 & 0,05 & 0,29 & 0,00 & 0,00 & 0,00 & 0,00 & 0,00 & 0,18 & 0,00 \\
\hline Pest & 0,02 & 0,08 & 0,02 & 0,02 & 0,01 & 0,01 & 0,02 & 0,04 & 0,06 & 0,04 \\
\hline Közép-Magyarország & 0,02 & 0,07 & 0,08 & 0,01 & 0,01 & 0,00 & 0,02 & 0,03 & 0,08 & 0,03 \\
\hline Fejér & 0,02 & 0,02 & 0,01 & 0,01 & 0,01 & 0,01 & 0,02 & 0,01 & 0,02 & 0,03 \\
\hline Komárom-Esztergom & 0,00 & 0,02 & 0,01 & 0,03 & 0,00 & 0,00 & 0,01 & 0,00 & 0,00 & 0,02 \\
\hline Veszprém & 0,31 & 0,66 & 0,31 & 0,71 & 0,37 & 0,41 & 0,46 & 0,47 & 0,38 & 0,42 \\
\hline Közép-Dunántúl & 0,12 & 0,26 & 0,12 & 0,28 & 0,14 & 0,16 & 0,18 & 0,19 & 0,16 & 0,18 \\
\hline Győr-Moson-Sopron & 3,07 & 2,57 & 2,63 & 3,34 & 3,32 & 4,05 & 3,77 & 3,95 & 3,58 & 4,56 \\
\hline Vas & 10,29 & 8,92 & 8,33 & 7,66 & 8,94 & 7,45 & 8,81 & 6,86 & 7,42 & 5,17 \\
\hline Zala & 1,14 & 2,00 & 2,13 & 1,98 & 1,23 & 1,61 & 1,57 & 2,10 & 1,98 & 1,81 \\
\hline Nyugat-Dunántúl & 4,40 & 4,21 & 4,11 & 4,13 & 4,25 & 4,22 & 4,53 & 4,19 & 4,18 & 3,84 \\
\hline Baranya & 0,56 & 0,70 & 0,71 & 0,50 & 0,52 & 0,44 & 0,62 & 0,71 & 1,04 & 0,49 \\
\hline Somogy & 1,10 & 1,09 & 1,08 & 1,12 & 1,96 & 0,56 & 0,71 & 0,76 & 0,68 & 0,44 \\
\hline Tolna & 0,03 & 0,09 & 0,10 & 0,02 & 0,12 & 0,45 & 0,15 & 0,02 & 0,02 & 0,38 \\
\hline
\end{tabular}


Táj-és környezetgazdálkodás

\begin{tabular}{|l|c|c|c|c|c|c|c|c|c|c|} 
Dél-Dunántúl & 0,65 & 0,70 & 0,71 & 0,64 & 1,02 & 0,50 & 0,54 & 0,56 & 0,63 & 0,44 \\
\hline Borsod-Abaúj-Zemplén & 0,02 & 0,02 & 0,02 & 0,44 & 0,09 & 0,11 & 0,05 & 0,01 & 0,10 & 0,05 \\
\hline Heves & 0,10 & 0,13 & 0,22 & 0,15 & 0,24 & 0,25 & 0,31 & 0,20 & 0,17 & 0,31 \\
\hline Nógrád & 0,00 & 0,02 & 0,00 & 0,00 & 0,00 & 0,00 & 0,01 & 0,00 & 0,00 & 0,03 \\
\hline Észak-Magyarország & 0,04 & 0,05 & 0,07 & 0,27 & 0,12 & 0,13 & 0,12 & 0,07 & 0,10 & 0,12 \\
\hline Hajdú-Bihar & 0,75 & 0,75 & 0,98 & 0,74 & 0,75 & 0,83 & 0,88 & 0,83 & 0,73 & 1,05 \\
\hline Jász-Nagykun-Szolnok & 0,25 & 0,55 & 0,82 & 0,41 & 0,49 & 0,76 & 0,46 & 0,41 & 0,71 & 0,83 \\
\hline Szabolcs-Szatmár-Bereg & 0,08 & 0,40 & 0,38 & 0,38 & 0,30 & 0,29 & 0,28 & 0,35 & 0,37 & 0,18 \\
\hline Észak-Alföld & 0,36 & 0,56 & 0,72 & 0,50 & 0,51 & 0,62 & 0,54 & 0,53 & 0,60 & 0,68 \\
\hline Bács-Kiskun & 0,51 & 0,68 & 0,89 & 0,74 & 0,60 & 1,04 & 1,11 & 0,72 & 0,72 & 0,95 \\
\hline Békés & 2,98 & 2,24 & 1,77 & 2,33 & 2,17 & 2,50 & 2,20 & 3,25 & 2,71 & 2,93 \\
\hline Csongrád & 0,90 & 0,87 & 0,91 & 0,69 & 0,52 & 0,38 & 0,12 & 0,55 & 0,62 & 0,95 \\
\hline Dél-Alföldd & 1,33 & 1,18 & 1,15 & 1,19 & 1,04 & 1,31 & 1,19 & 1,41 & 1,27 & 1,54 \\
\hline
\end{tabular}

Forrás: KSH adatok alapján saját számítás

\subsection{A hazai lúdtenyésztés területi specializációja}

A lúdállomány a vizsgált időszakban hektikusan alakult. Ugyanakkor az állomány létszáma csökkenő tendenciát mutat. 2004-ben a lúdállomány 2127 ezer darabot volt, ami 2013ra 1631 ezer darabra csökkent. Ez 23,3\%-os csökkenést jelent a bázisévről a tárgyévre. A csökkenés oka a nemzetközi versenyképesség romlásában keresendő. De e mellett a tartósan alacsony jövedelmezőség és a technikai színvonal alacsony volta is a befolyásoló tényezők között szerepel. 2004-ben a lúdtenyésztésre elsősorban az alföldi megyék (Csongrád, Bács-Kiskun, Békés) specializálódtak. 2013-ra Csongrád megye specializáltsága csökkent, ugyanakkor növekedett Bács-Kiskun és Békés megye specializáltsága. Az előbbiek mellett 2013-ra növekedés tapasztalható Hajdú-Bihar és Pest megyében is.

3. táblázat: A hazai lúdtenyésztés területi specializációja

\begin{tabular}{|l|c|c|c|c|c|c|c|c|c|c|}
\hline Területegység & $\mathbf{2 0 0 4}$ & $\mathbf{2 0 0 5}$ & $\mathbf{2 0 0 6}$ & $\mathbf{2 0 0 7}$ & $\mathbf{2 0 0 8}$ & $\mathbf{2 0 0 9}$ & $\mathbf{2 0 1 0}$ & $\mathbf{2 0 1 1}$ & $\mathbf{2 0 1 2}$ & $\mathbf{2 0 1 3}$ \\
\hline Budapest & 0,03 & $\mathbf{2 0} 56$ & 0,04 & 0,03 & 0,08 & 0,37 & 0,55 & 0,96 & 0,47 & 0,46 \\
\hline Pest & 0,33 & 2,23 & 0,35 & 0,33 & 0,24 & 0,41 & 0,54 & 0,68 & 0,85 & 1,09 \\
\hline Közép-Magyarország & 0,27 & 1,87 & 0,28 & 0,27 & 0,20 & 0,39 & 0,54 & 0,74 & 0,77 & 0,97 \\
\hline Fejér & 0,05 & 0,12 & 0,01 & 0,09 & 0,03 & 0,01 & 0,07 & 0,14 & 0,14 & 0,26 \\
\hline Komárom-Esztergom & 0,46 & 0,36 & 0,34 & 0,14 & 0,08 & 0,03 & 0,14 & 0,55 & 0,41 & 0,30 \\
\hline Veszprém & 0,02 & 0,07 & 0,02 & 0,02 & 0,02 & 0,05 & 0,03 & 0,04 & 0,05 & 0,13 \\
\hline Közép-Dunántúl & 0,12 & 0,15 & 0,08 & 0,07 & 0,03 & 0,03 & 0,07 & 0,18 & 0,16 & 0,22 \\
\hline Györ-Moson-Sopron & 0,02 & 0,21 & 0,12 & 0,17 & 0,14 & 0,17 & 0,32 & 0,37 & 0,35 & 0,27 \\
\hline Vas & 0,01 & 0,04 & 0,02 & 0,02 & 0,01 & 0,02 & 0,04 & 0,07 & 0,02 & 0,04 \\
\hline Zala & 0,03 & 0,09 & 0,03 & 0,03 & 0,04 & 0,04 & 0,04 & 0,04 & 0,04 & 0,08 \\
\hline Nyugat-Dunántúl & 0,03 & 0,11 & 0,06 & 0,08 & 0,07 & 0,08 & 0,14 & 0,18 & 0,15 & 0,14 \\
\hline Baranya & 0,18 & 0,06 & 0,03 & 0,03 & 0,09 & 0,14 & 0,15 & 0,12 & 0,09 & 0,23 \\
\hline Somogy & 0,08 & 0,20 & 0,07 & 0,12 & 0,02 & 0,06 & 0,06 & 0,10 & 0,08 & 0,08 \\
\hline Tolna & 0,05 & 0,08 & 0,03 & 0,06 & 0,15 & 0,12 & 0,10 & 0,09 & 0,27 & 0,20 \\
\hline Dél-Dunántúl & 0,10 & 0,13 & 0,05 & 0,08 & 0,08 & 0,10 & 0,10 & 0,10 & 0,13 & 0,16 \\
\hline Borsod-Abaúj-Zemplén & 0,06 & 0,15 & 0,05 & 0,05 & 0,05 & 0,08 & 0,04 & 0,08 & 0,07 & 0,18 \\
\hline Heves & 0,14 & 0,29 & 0,07 & 0,12 & 0,10 & 0,16 & 0,35 & 0,10 & 0,10 & 0,21 \\
\hline Nógrád & 0,02 & 0,40 & 0,08 & 0,12 & 0,09 & 0,05 & 0,08 & 0,09 & 0,03 & 0,23 \\
\hline Észak-Magyarország & 0,08 & 0,24 & 0,06 & 0,09 & 0,08 & 0,10 & 0,14 & 0,09 & 0,07 & 0,20 \\
\hline Hajdú-Bihar & 0,72 & 3,12 & 0,81 & 1,87 & 0,52 & 1,28 & 1,86 & 2,69 & 2,95 & 2,49 \\
\hline Jász-Nagykun-Szolnok & 0,99 & 0,98 & 0,87 & 0,60 & 0,17 & 0,11 & 1,24 & 0,24 & 0,61 & 0,55 \\
\hline Szabolcs-Szatmár-Bereg & 0,67 & 0,46 & 0,23 & 0,16 & 0,08 & 0,29 & 0,08 & 0,29 & 0,24 & 0,23 \\
\hline Észak-Alföld & 0,79 & 1,50 & 0,63 & 0,87 & 0,25 & 0,55 & 1,05 & 1,07 & 1,26 & 1,09 \\
\hline Bács-Kiskun & 2,37 & 3,16 & 4,53 & 4,09 & 6,10 & 6,15 & 5,00 & 4,95 & 5,20 & 4,79 \\
\hline & & & & & & & & & \\
\hline
\end{tabular}


Komarek Levente: A hazai baromfitenyésztés területi specializációjának jellemző vonásai ...

\begin{tabular}{|l|c|c|c|c|c|c|c|c|c|c|} 
Békés & 1,63 & 1,90 & 1,49 & 2,23 & 2,19 & 1,62 & 2,40 & 1,76 & 1,72 & 1,87 \\
\hline Csongrád & 9,82 & 1,44 & 6,58 & 5,41 & 4,30 & 3,18 & 1,92 & 2,14 & 0,98 & 1,45 \\
\hline Dél-Alföld & 3,94 & 2,38 & 4,13 & 3,86 & 4,53 & 4,11 & 3,50 & 3,34 & 3,16 & 3,11 \\
\hline
\end{tabular}

\subsection{A hazai kacsatenyésztés területi} specializációja

A kacsa az egyedüli, amely a baromfiállományon belül növekvő tendenciát mutatott a vizsgált időszakban. Állománya 2004-ben 2797 ezer darab volt, amely 2013-ra 4265 ezer darabra növekedett. Csúcspontját 2010-ben érte el, amikor az állomány elérte az 5813 ezer darabot. A növekedés elsősorban az exportnak köszönhető, de a hazai fogyasztás bővülésével is magyarázható. 2004-ben a kacsatenyésztésre az alföldi térségek specializálódtak. Ezek közül kiemelkedik Bács-Kiskun megye. E mellett még megemlíthető ezen a téren Csongrád és Békés megye is. 2013-ban erősödött a specializáció Csongrád és Hajdú-Bihar megyében. Ezzel szemben csökkent a specializáció Békés megyében. A korábbi sereghajtó Bács-Kiskun megye továbbra is megőrizte vezető szerepét, de specializációjában kisebb visszaesés tapasztalható.

4. táblázat: A hazai kacsatenyésztés területi specializációja

\begin{tabular}{|c|c|c|c|c|c|c|c|c|c|c|}
\hline Területegység & 2004 & 2005 & 2006 & 2007 & 2008 & 2009 & 2010 & 2011 & 2012 & 2013 \\
\hline Budapest & 0,00 & 0,66 & 0,45 & 0,26 & 0,00 & 0,13 & 0,92 & 0,91 & 0,48 & 0,06 \\
\hline Pest & 0,26 & 0,43 & 0,27 & 0,22 & 0,11 & 0,09 & 0,08 & 0,10 & 0,11 & 0,23 \\
\hline Közép-Magyarország & 0,21 & 0,48 & 0,30 & 0,23 & 0,09 & 0,09 & 0,25 & 0,26 & 0,18 & 0,20 \\
\hline Fejér & 0,31 & 0,39 & 0,26 & 0,46 & 0,22 & 0,15 & 0,11 & 0,18 & 0,16 & 0,30 \\
\hline Komárom-Esztergom & 0,98 & 0,31 & 0,16 & 0,37 & 0,11 & 0,13 & 0,06 & 0,09 & 0,09 & 0,33 \\
\hline Veszprém & 0,18 & 0,17 & 0,22 & 0,19 & 0,11 & 0,05 & 0,03 & 0,05 & 0,06 & 0,17 \\
\hline Közép-Dunántúl & 0,40 & 0,29 & 0,23 & 0,34 & 0,16 & 0,11 & 0,07 & 0,11 & 0,11 & 0,25 \\
\hline Győr-Moson-Sopron & 0,19 & 0,33 & 0,17 & 0,18 & 0,11 & 0,08 & 0,07 & 0,08 & 0,09 & 0,19 \\
\hline Vas & 0,06 & 0,06 & 0,09 & 0,09 & 0,03 & 0,03 & 0,02 & 0,07 & 0,04 & 0,03 \\
\hline Zala & 0,09 & 0,15 & 0,09 & 0,16 & 0,09 & 0,07 & 0,04 & 0,06 & 0,09 & 0,10 \\
\hline Nyugat-Dunántúl & 0,11 & 0,19 & 0,12 & 0,14 & 0,08 & 0,06 & 0,05 & 0,07 & 0,08 & 0,11 \\
\hline Baranya & 0,25 & 1,19 & 0,25 & 0,26 & 0,18 & 0,13 & 0,06 & 0,13 & 0,12 & 0,17 \\
\hline Somogy & 0,17 & 0,20 & 0,19 & 0,27 & 0,15 & 0,12 & 0,05 & 0,10 & 0,10 & 0,15 \\
\hline Tolna & 0,36 & 0,47 & 0,37 & 0,44 & 0,25 & 0,20 & 0,13 & 0,18 & 0,13 & 0,26 \\
\hline Dél-Dunántúl & 0,24 & 0,59 & 0,25 & 0,31 & 0,19 & 0,15 & 0,07 & 0,13 & 0,11 & 0,18 \\
\hline Borsod-Abaúj-Zemplén & 0,24 & 0,25 & 0,25 & 0,29 & 0,22 & 0,14 & 0,06 & 0,15 & 0,11 & 0,15 \\
\hline Heves & 0,13 & 0,19 & 0,20 & 0,20 & 0,08 & 0,05 & 0,03 & 0,05 & 0,05 & 0,10 \\
\hline Nógrád & 0,18 & 0,26 & 0,13 & 0,20 & 0,08 & 0,07 & 0,06 & 0,09 & 0,08 & 0,29 \\
\hline Észak-Magyarország & 0,20 & 0,24 & 0,21 & 0,25 & 0,15 & 0,10 & 0,05 & 0,11 & 0,09 & 0,16 \\
\hline Hajdú-Bihar & 0,49 & 0,53 & 0,41 & 0,59 & 0,33 & 1,19 & 0,66 & 0,85 & 1,07 & 1,38 \\
\hline Jász-Nagykun-Szolnok & 0,39 & 1,18 & 0,74 & 0,57 & 0,41 & 0,26 & 0,09 & 0,20 & 0,14 & 0,20 \\
\hline Szabolcs-Szatmár-Bereg & 0,53 & 0,41 & 0,47 & 0,59 & 0,27 & 0,19 & 0,12 & 0,21 & 0,21 & 0,22 \\
\hline Észak-Alföld & 0,47 & 0,70 & 0,54 & 0,58 & 0,34 & 0,55 & 0,29 & 0,42 & 0,47 & 0,60 \\
\hline Bács-Kiskun & 6,78 & 5,13 & 6,57 & 6,10 & 6,89 & 5,18 & 6,79 & 6,41 & 7,06 & 6,36 \\
\hline Békés & 1,25 & 1,50 & 1,08 & 1,59 & 0,97 & 0,72 & 2,50 & 0,62 & 0,65 & 0,69 \\
\hline Csongrád & 1,42 & 1,74 & 1,82 & 1,48 & 3,18 & 6,43 & 2,48 & 4,42 & 3,16 & 3,26 \\
\hline Dél-Alföld & 3,87 & 3,26 & 3,83 & 3,67 & 4,27 & 4,17 & 4,50 & 4,24 & 4,26 & 3,93 \\
\hline
\end{tabular}

Forrás: KSH adatok alapján saját számítás 


\section{KÖVETKEZTETÉSEK}

A hazai baromfiállomány területi specializációjának vizsgálatánál megállapítható, hogy a specializációs mutató értékei változó képet mutatnak. A baromfifajták közül valamennyi esetben megállapítható területi specializációs növekedés és csökkenés egyaránt, de ha a tendenciákat vizsgáljuk, akkor elmondhatjuk, hogy a területi specializáció a pulyka, a lúd és a kacsa esetén nem, míg a tyúkfélék tenyésztése esetén nagyobb változásokat produkál. A térségi szempontokat figyelembe véve a specializáció nyertesei a baromfitenyésztés esetében a Dunától keletre eső alföldi területek, ezen belül is kitüntetett szerepe van a Dél-Alföldi régiónak. Ez azt jelenti, hogy ezen alföldi területeken a legnagyobb specializációs értékkel rendelkező baromfitenyésztési ágazat adja az adott térség (pl. megye, régió) baromfiállományának jelentős részét. Ezen baromfitenyésztési ágazat a térség baromfiállományának a „vázát” képezi, amely körül kialakul a tenyésztési komplexum és amely meghatározza a fejlődés irányát, jelentősen befolyásolja a többi állattenyésztési ágazatot. E mellett térségformáló ereje van és a rendelkezésre álló kedvező természetitársadalmi-gazdasági feltételek kihasználásával elősegíti a minimális munkaráfordítás mellett maximális hozam gazdasági törekvés érvényesítését. A specializációt képviselő baromfitenyésztési ágazat mellett fontos szerep jut az ágazatot kiszolgáló, kiegészítő, valamint a helyi szükségleteket ellátó, tehát jórészt helyi jelentőségú ágazatok fejlesztésének.

$A z$ elkészült vizsgálat megítélésem szerint jól tükrözi a baromfitenyésztés területén az elmúlt egy évtized alatt lejátszódó folyamatokat és tendenciákat. Több esetben is a rendelkezésre álló adatokból megállapítható, hogy az elmúlt években a vizsgált baromfiállomány esetében a pulykaállomány kivételével csökkenő tendencia figyelhető meg. A csökkenésben szerepe volt a 2006-2007 közötti madárinfluenzának, illetve a 2008-as takarmányár robbanásnak, amely tovább mélyítette a baromfitenyésztés válságát. $E$ mellett tovább nehezítette a helyzetet az energiaárak jelentős megugrása is (pl. 2006-2011 között a villamosenergia ára 22\%-kal, a földgázé 99\%-kal, a gázolajé 50\%-kal növekedett), de olykor az alacsony felvásárlási árakkal, a nehezebb értékesítési lehetőségekkel, a folyamatosan beáramló olcsó, gyengébb minőségú külföldről importált termékekkel magyarázható még a baromfiállomány csökkenése. Így hazánkban jelenleg a baromfitenyésztés sok esetben csak veszteségesen múködő esetenként leépülést fontolgató tevékenységnek számít.

A baromfitenyésztés területén az állomány olykor jelentősebb visszaesés után csak megfelelő körültekintéssel, jól átgondolt agrárpolitika mellett, az Európai Uniós viszonyok figyelembevételével és színvonalas szakmai irányítással alakulhat a jövőben kedvezőbben a helyzete. Szükséges lenne a versenyképesség javítása, amely jelentősebb beruházások, illetve a termelési technológiai folyamatok korszerúsítésével valósulhatna meg. Hosszú és középtávon nagyon fontos lenne a baromfiipari integráció erősítése, hogy a baromfitenyésztés növekvő szerepet tölthessen be hazánk agrárgazdaságában, a vidék fejlődésében, ezáltal tovagyưrǔző multiplikatív hatást kifejtve. 


\section{BIBLIOGRÁFIA}

[1.] Bodnár K. - Horváth J. (2005): Különböző állattenyésztési ágazatok tőkeszükséglete. (in. A mezőgazdaság tőkeszükséglete és hatékonysága szerk.: Jávor A.). DAC AVK, Debrecen pp. 97-103.

[2.] Komarek L. (2003): Baromfiágazati diagnosztika. Magyar Mezőgazdaság. 43. sz. pp. 18-19.

[3.] Komarek L. (2004): A tágabb értelemben vett húsipar árualapjának változása a DélAlföldön, különös tekintettel a rendszerváltozás utáni időszakra. pp. 181-186. (In. Abonyiné Palotás J. - Komarek L. szerk.: 40 éves a Szegedi Tudományegyetem Gazdaságés Társadalomföldrajz Tanszék. Gold Press, Szeged. 224. p.

[4.] Komarek L. (2007): A Dél-Alföldi régió súlyának, szerepének alakulása a hazai agrártermelésben. Comitatus - Önkormányzati Szemle. 17. évf. 9. sz. pp. 52-64.

[5.] Komarek L. (2008a): Állatállományunk alakulása. Magyar Mezőgazdaság. 63. évf. 14. sz. pp. 16-17.

[6.] Komarek L. (2008b): A hazai állatállomány alakulásának főbb jellemzői. A Földrajz Tanítása. XVI. évf. 4. sz. pp. 13-19.

[7.] Komarek L. (2008c): A Dél-Alföld agrárszerkezetének sajátosságai. Csongrád Megyei Agrár Információs, Szolgáltató és Oktatásszervező Kht, Szeged. 143. p.

[8.] Komarek L. (2011): A hazai húsipari árualap abszolút specializációjának és koncentrációjának időbeni és területi alakulása. Agrár- és Vidékfejlesztési Szemle. 6. évf. 2. sz. pp. 239-245.

[9.] Popp J. - Udovecz G. (2003): A baromfihús piacszabályozása. AKI, Budapest. 25. p.

[10.] Popp J. (2008a): Az állati termékek piaci kilátásai. Magyar Mezőgazdaság. 63. évf. 36. sz. pp. 6-8.

[11.] Popp J. (2008b): Az állati termékek piaci kilátásai (II.). Magyar Mezőgazdaság. 63. évf. 37. sz. pp. 10-12.

[12.] Popp J. (2013): A baromfiágazat globális helyzete és kilátásai (I.). Baromfiágazat. 13. évf. 4. sz. pp. 4-6; 9-11.

[13.] Popp J. (2014): A baromfiágazat globális helyzete és kilátásai (II.). Baromfiágazat. 14. évf. 1. sz. pp. 4-6; 9-11.

[14.] Szőllősi L. (2008): A vágócsirke vertikum modellezése és gazdasági elemzése egy, az ÉszakAlföldi régióban múködő integráció alapján. Debreceni Egyetem, Debrecen. 194. p. (PhD értekezés, kézirat).

[15.] Troján Sz. (2010): A baromfi-(broiler) és sertéshús termékpályák szereplőinek jövedelemviszonyai. Nyugat-magyarországi Egyetem, Mosonmagyaróvár. 162. p. (PhD értekezés, kézirat). 